\title{
No fish, no house, no melons: The earliest Aboriginal guides in colonial New South Wales
}

\author{
Annemarie McLaren
}

\begin{abstract}
Aboriginal individuals - often men - who went with the colonists on their travels in colonial New South Wales performed various, often vital, roles. While this is well known, less attention has been paid to the ways in which relationships developed between the colonists and those guiding, or how these relationships were dependent on meeting the needs and desires of all involved. By teasing apart some of the earliest, shakiest beginnings of Aboriginal men travelling with and 'guiding' the colonists, this article suggests that guiding was negotiated from the outset - the product of intercultural dialogue and deliberation - and that it is a phenomenon that benefits from being more fully contextualised.
\end{abstract}

There were many tasks to be completed before the expeditionary party turned in for the night. Water had to be drawn, timber chopped and supper prepared, but Colebee and Balloderry had not assisted at all. Having eaten their fill - one officer said they had 'stuffed themselves' - they lay down by the fire and slept. ${ }^{1}$ The naval officers had thought that these 2 Aboriginal men would prove useful to the success of their exploration, and in later decades in New South Wales, Aboriginal guides would assist travellers and explorers as cooks, hunters, stockmen and more. Yet here, during this expedition of April 1791 just west of the settlements at Sydney Cove and Rose Hill, these understandings were yet to develop. Instead, an association beset with misunderstanding was about to unfold.

1 Tench, 'Settlement at Port Jackson', 225. 
Indigenous guides and brokers have received much attention in recent years. There is a growing Australian oeuvre committed to re-examining who they were and their roles during colonial expeditions. ${ }^{2}$ In these recent considerations, the 'hidden histories' of exploration and Indigenous involvement form the focus, and a range of methodologies are employed to search for ways of reading Indigenous involvement, their skills, and their impact on expeditionary outcomes in heavily mediated sources. This scholarship has challenged the aura surrounding expeditionary travel, rendering it a complex affair and the position of a heroic leader highly dubious. We now know just how central the involvement of Aboriginal guides could be, and that they could make expeditionary journeys faster or frustrate their goals. ${ }^{3}$ We also know that their involvement could be strategic, that they could have their own reasons for travelling and that they could exert pressure in negotiating the terms of their engagement. ${ }^{4}$

Less attention has been paid to the ways in which relationships between Aboriginal guides and the colonists developed, or how these were dependent on the ongoing negotiation of the needs of all involved. Guiding became a key part of the intercultural social world by the 1820 s, with prospectors, newly arrived immigrants, long-term settler gentlemen and more all enjoying the services of Aboriginal guides. So asking how these relationships and understandings developed - and the motivations of these guides - seem pressing questions. ${ }^{5}$ Don Baker has delivered key insights here, noting that those Aboriginal individuals who were 'hired help' during the expeditions of surveyor Thomas Mitchell in New South Wales in the late 1820s had 'some degree of independence' and set the job and the price, with the number of days agreed upon negotiated by holding up fingers. ${ }^{6}$ Similarly, Tiffany Shellam, one of the few historians to consider the origins of guiding relationships in the new and fragile cross-cultural worlds of the British military outposts on the west coast of Australia, has persuasively argued that the benefits of expeditions 'flowed both ways', that they were 'collaborative accomplishments' and that there were 'mutual impacts'. ${ }^{7}$ Only recently has a volume appeared that seeks to centre the motivations of mobile Indigenous actors in colonial Australia and New Zealand, including the

\footnotetext{
2 For example, Blyton, 'Harry Brown', 63-82; Douglas, Science, Voyages, and Encounters; Jones, 'The Theatre of Contact'; Konishi, Nugent and Shellam, Indigenous Intermediaries; Shellam et al., Brokers and Boundaries; Stanfield, 'Looking Across'; Thomas, Expedition into Empire.

3 For example, Baker, 'Exploring with Aborigines', 22; McLaren, 'Entangled Life of Goggey'; Sydney Gazette, 23 September $1804,2$.

4 Baker, 'Exploring with Aborigines'; Shellam, 'Manyat's "Sole Delight"'.

5 For example, Atkinson, State of Agriculture, 64. Dunn has demonstrated that guiding in the Hunter Valley shifted over time with different waves of colonists. Dunn, 'Aboriginal Guides', 72-73, 79.

6 Baker, 'Exploring with Aborigines', 22, 37.

7 Shellam, Shaking Hands, 139.
} 
ways in which 'Indigenous people affected mobility, such as through being involved in its creation, shaping its operations, making use of networks for their own ends and travelling for the sake of travel'. ${ }^{8}$

In this article, I want to wind back the clock and consider how guiding relationships first developed between Aboriginal people and expeditionary parties in New South Wales. Under what circumstances, and with what intention and anticipation, did colonists desire and acquire Aboriginal help on their expeditionary travels? And with what understandings and expectations did Aboriginal men travel with these colonists? In what follows, some of the earliest, shakiest beginnings of Aboriginal men travelling with the colonists are examined. Though these sources require interpretive caution, as discussed in the next section, my reading indicates that the first time that Aboriginal individuals accompanied the colonists on a true 'expedition' - one that had defined goals and was hierarchically organised - that they had no cognisance of what exploration was or what it meant to 'guide'. This was a curious case of guiding, then, as these Aboriginal men would have abandoned the expedition had they known the way home.

\section{Sources: 'The season for observing'}

The main primary material in the lengthy accounts of Watkin Tench and John Hunter drawn upon here is familiar to historians of colonial Australia, as is the expedition described. This involved a party led by Governor Phillip in 1791 to discover whether the Hawkesbury and Nepean rivers were a single watercourse. In relying on these accounts, caution is of course required. The publications are travel literature, part of a genre popularly devoured across England and the Continent through feverishly translated editions. ${ }^{10}$ Both authors were well aware of the novelty and high stakes of establishing a penal settlement on the other side of the world and so were anxious to chronologically record all the happenings of the colony. ${ }^{11}$ Yet, written in the wake of voyages of exploration with lofty scientific aims, the capacity to contribute to this knowledge through observations of the natural world and its indigenous inhabitants was another objective: this was, as Greg Dening described, 'the season for observing' ${ }^{12}$ The toil of this expedition was completed in the service of England and Empire, yet it was also an adventure, and one that held scientific

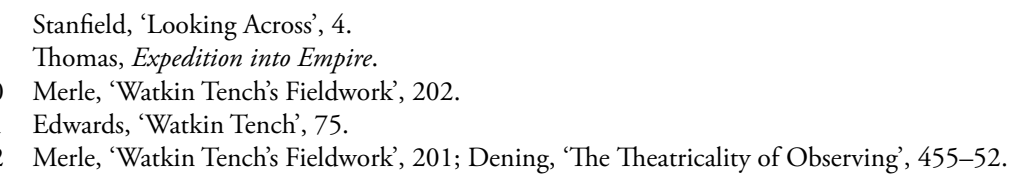


promise. ${ }^{13}$ So these accounts were composed not only with career, reputation and an audience in mind, but also were written with specific notions of the duties of exploration, of scientific questing and the nature of genteel English manhood. ${ }^{14}$

This makes for a heady mix. On top of this, Enlightenment science and philosophical ideas about the nature of society were not entirely coherent. There were contradictory threads, and the science itself was changing and would soon harden into a rigid system of racial classification. ${ }^{15}$ While Tench said that he chose to describe this episode among many others for its 'amusing' detail, these tensions and goals make themselves felt. ${ }^{16} \mathrm{~A}$ capacity for personal observation was crucial here; as we shall see, he used the first person and was sure to record as much ethnographic information as possible about hairstyles, diet, healing customs and more. ${ }^{17}$ Tench was an 'improver' and disagreed with Rousseau's romanticisation of primitive society; for him, the very conditions of Aboriginal society, what he considered to be the vagaries of the climate and the scarcity of food, were degrading. ${ }^{18}$

Yet Tench also insisted that, as individuals, many Aboriginal people held admirable qualities. In this particular expeditionary case, he was describing the actions of men he knew well and, at least at this point, he well liked, even calling Balloderry their 'travelling friend'. ${ }^{19}$ This created conditions for a 'mixture of interest and feeling' that 'deeply informed travelling ethnographies', as Harry Liebersohn has described. ${ }^{20}$ Hunter was different to Tench. He was decades older, and he was skilled in creating navigational sketches and charts. Hunter also appreciated science and had sent botanical specimens back to Joseph Banks and others in England and published his own book of natural history drawings. ${ }^{21} \mathrm{He}$ had left the colony just before this expedition took place (though later he would return as Governor), and was relying on Governor Phillip's journal for his secondhand retelling. In including it in his chronicle of the colony in such a lengthy way, Hunter too was aware of the natural history and ethnographic material it contained, including observations about different states of society even amongst quite geographically close Aboriginal groups.

While there are limitations to the accounts in these journals then, the detail is more convincing than in other moments. Here, Tench and Hunter describe people already well known, and their doings and interactions are richly narrated so that even with minor discrepancies between the accounts, they remain coherent. So the same

13 Fabricant, 'Eighteenth-Century Travel Literature', 742-43.

14 Downing, Restless Men, chapter 4.

15 Douglas, 'In the Event'; Douglas, 'Philosophers, Naturalists'.

16 Tench, 'Settlement at Port Jackson', 223.

17 Greenblatt, Marvellous Possessions, 122-28.

18 Fabricant, 'Eighteenth-Century Travel Literature'; Merle, 'Watkin Tench's Fieldwork', 208; Buchan, Empire

of Political Thought, 59-60; Tench, 'Settlement at Port Jackson', 239.

19 Tench, 'Settlement at Port Jackson', 239.

20 Liebersohn, The Travelers' World, 140.

21 Groom, A Steady Hand. For a good discussion of Hunter, see Clendinnen, Dancing with Strangers, 37-43. 
colonial writers who at other times could fall back on tropes and hearsay are here more reliable in their observations. ${ }^{22}$ In their provision of a narrative that unfolds day by day, both Tench and Hunter provide an arc of happenings from which the motivations and changing understandings of the Aboriginal men who volunteered to go along can be considered, including the shifting dynamics of the expeditionary unit, as race, hierarchy and different expectations came into conflict. As Maria Nugent has demonstrated in her thoughtful tracing of interactions between the Gweagal at Botany Bay and Captain Cook over 12 days in 1770, and as Tiffany Shellam demonstrated in cross-cultural relations at King George Sound (Western Australia) over 6 months from 1826, this can be a useful approach, even when the meanings of Indigenous action are 'more or less opaque', to draw on Bronwen Douglas. ${ }^{23}$ With other meetings scattered through the accounts, these journals also point to the political landscape in which the colonists and their companions were embedded and, more particularly, allow a closer examination of how the very acts of guiding, brokering and mediating that were to become a phenomenon in New South Wales and other colonies began to develop. ${ }^{24}$

\section{Setting off}

Aboriginal people first travelled with the Governor and his party, at his request, in early December 1790. It was 3 months after the spearing of Governor Phillip, and amicable relations had been restored. ${ }^{25}$ After the establishment of an agricultural farm on soils hoped to be more fertile than those at Sydney Cove, Rose Hill had become a bustling scene of clearing, sawing and building, 15 miles from Sydney. From here, Phillip began to make a series of 'excursions' ${ }^{26}$ Leaving Sydney Cove at 8 in the morning, he arrived at Rose Hill before noon, travelling by boat along the river systems that were the Indigenous highways of south-east Australia. ${ }^{27}$

It was on one such trip that 'several of the natives were desirous of accompanying him', as naval officer Captain John Hunter wrote in his journal. ${ }^{28}$ While the remonstrations of Barangaroo - the wife of the well-known Wangal man Bennelong - meant that Bennelong was unable to join the expedition, Colebee and the 2 other

\footnotetext{
22 Konishi, 'Wanton With Plenty'; Conor, Skin Deep, 90-151. For a brief consideration of the ways in which single authors and writers could produce both stereotypical depictions as well as more convincing ones in the New South Wales context, see Karskens, The Colony, 520.

23 Nugent, Captain Cook; Shellam, Shaking Hands. For a full methodological and historiographical discussion of these close-readings, see Douglas 2006: 3-38. For a close reading of a single event, see Clendinnen, 'Spearing the Governor'. For the Pacific, see Elena Govor's analysis of the 12-day Russian stay in what became the Marquesas Islands. Govor, Twelve Days at Nuku Hiva.

24 Jones, 'The Theatre of Contact'.

25 Clendinnen, 'Spearing the Governor', 157-74.

26 Hunter, Transactions at Port Jackson, 469-70.

27 Hunter, Transactions at Port Jackson, 402; Goodall and Cadzow, Rivers and Resilience, 31-32.

28 Hunter, Transactions at Port Jackson, 489.
} 
unnamed Aboriginal men went along. ${ }^{29}$ In this, there are not many surprises. There is now a rich historiography positing the strategic relationships that many Aboriginal individuals forged with the colonists, and the Aboriginal men mentioned as going along are all familiar characters who had high levels of exposure to and interaction with the colonists at Sydney Cove. ${ }^{30}$ On the journey, however, despite being well fed, Phillip was taken aback when all his Aboriginal companions were soon eager to return to Sydney. While Phillip too had previously often returned to Sydney Cove from Rose Hill the same day, a house had now been built for him and it is likely that he expected his Aboriginal companions would sleep at his second house here as they did at his home in Sydney. ${ }^{31}$

His surprise continued when the boat sent to return them to Sydney came back with Bennelong and Barangaroo on board. The latter had, as noted, prevented her husband from joining the party at Rose Hill earlier in the day. Yet evidence that the social relations with the colonists required a good amount of negotiation between the Aboriginal people of Sydney Cove was again displayed: Bennelong and Barangaroo both dined with the Governor and were given all they asked for, but then Barangaroo insisted upon returning to Sydney. So the Governor, having been told by Bennelong that Barangaroo would cry if not permitted to return, was obliged at a late hour of the afternoon to ferry his Aboriginal companions back to Sydney. Phillip was perplexed: he knew that the preference of these coastal people was for fish over the food of the inland. For this reason, he had fed them fish along with possum, and yet it had not been enough to entice them to remain. Once more he must have realised that negotiating the intricacies of strategic 'conciliatory' relationships with these people would not be straightforward. ${ }^{32}$ Bennelong and Bangaroo, like those individuals who would in the future travel with the colonists, had their own reasons and motivations.

It was in the context of such short overnight trips to Rose Hill with the Governor that the account of the first landed exploratory journey during which Aboriginal people were present can be situated. ${ }^{33}$ This 6-day, 21-person expedition of 1791 was more of an exploratory expedition than any other in the colony to that date. Expeditions were always hierarchical arrangements modelled on the practices of military and naval cultures, but with Governor Phillip at the expedition's helm, as well as JudgeAdvocate Collins and his servant, Surgeon White, astronomer Lieutenant William Dawes, Captain Watkin Tench, 8 soldiers and 3 convict marksmen, almost the entire

\footnotetext{
29 Tench, 'Settlement at Port Jackson', 223.

30 For example, see Fullagar, Savage Visit, 171-87. For a sample of the strategic interactions Indigenous individuals forged with colonists elsewhere, see Liebersohn, The Travelers' World, 141.

31 Hunter, Transactions at Port Jackson, 469.

32 Hunter, Transactions at Port Jackson, 490.

33 For a summary of exploratory journeys in Sydney to date, none of which involved Aboriginal people, see Favenc, History of Australian Exploration, 43-46.
} 
social spectrum of the colony was represented in a particularly stratified way. ${ }^{34}$ Eager to communicate the aspects of this expedition that would be of interest to curious readers of travel literature - and to demonstrate toil in the dutiful service of Empire - Tench conveyed a sense of what such expeditions meant in practice. Each person except the Governor carried his own heavy knapsack and was encumbered by a kettle, axe, blanket, gun and canteen, all the while being bothered by insects. It was Dawes who was given the unenviable task of counting his footsteps to calculate the distances travelled. Using the compass by day to steer, at night the paces and directions were recorded and 'worked by a traverse table, in the manner a ship's reckoning is kept': an example of how landed expeditions reflected their oceanic heritage. ${ }^{35}$ Their goal was to trace the course of the Nepean River, flowing roughly north-south to Sydney's west, and see if it joined the Hawkesbury River that flowed west-east to Sydney's north. Although this expedition was modest in comparison to future, much lengthier journeys, it was no less imperial. Waterways were key to navigation, settlement and agriculture in any colony, and if 'the explorer was the foot-soldier of geography's empire', as Felix Driver (building on Joseph Conrad) contends, in settler-colonies such travellers were also the outriders of settlement: they were travelling 'towards what will become their country'. ${ }^{36}$

It was Colebee and Balloderry, 2 Aboriginal people well known to the colonists, who asked to join the party. They came as 'volunteers', wrote Tench, with Hunter adding that they were 'desirous of joining this party' ${ }^{37}$ Colebee was a Cadigal man, inhabiting the suburbs and harbour of today's eastern Sydney, a man who had survived smallpox and was considerably scarred, and who, along with Bennelong, had been kidnapped by the colonists in 1789 but soon escaped, yet whose relationship with them later continued. ${ }^{38}$ Balloderry was a Burramattagal man from near Parramatta and a close associate of the Aboriginal people about Sydney Cove. ${ }^{39}$ Both Colebee and Balloderry had been 'assured that we should not stay out many days, and that we should carry plenty of provisions' ${ }^{40}$ Colebee 'stipulated ... that during his absence, his wife and child should remain at Sydney under our protection, and be supplied with provisions' ${ }^{41}$ Here, Tench also left a clue as to how the changing socioeconomic world was being negotiated: this excursion with colonists was a novelty that had to be considered in light of pre-existing obligations to kin. Barangaroo, for instance, had used these ties to insist that Bennelong not go along with the colonists - and not for the first time. A few months earlier Barangaroo had violently opposed Bennelong going to visit Governor Phillip. This was, perhaps, an unsurprising reaction given

34 Tench, 'Settlement at Port Jackson', 223.

35 Driver, Geography Militant, 2.

36 Driver, Geography Militant, 3; Veracini, 'Settler Colonial Expeditions', 58.

37 Tench, 'Settlement at Port Jackson', 223; Hunter, Transactions at Port Jackson, 513.

38 Smith, 'Bennelong among His People', 11; Smith, 'Colebee'.

39 Smith, 'Bennelong among His People', 13.

40 Tench, 'Settlement at Port Jackson', 223.

41 Tench, 'Settlement at Port Jackson', 223 
that Bennelong had previously been kidnapped by Phillip, his duties to his family unit disrupted. The result was that Reverend Johnson and an Aboriginal woman, Abaroo, stayed with Barangaroo as sorts of hostages to assure Bennelong's prompt and safe return. ${ }^{42}$

\section{The first day}

With Colebee's food-gathering and other duties to his family delegated, he and Balloderry set off with the expeditionary party. In what seems to have been foresight to prevent complaints from usually unencumbered people, each was equipped with a pack much lighter than the others, with the greater part of their share of equipment and provisions delegated to the soldiers and gamekeepers. ${ }^{43}$ They steered by compass from the Governor's house in Rose Hill, the nature of the country carefully observed: 'good, full grass'; 'poor stony country'; or 'dry, arid soil'. ${ }^{44}$ Spirits were high, at least for their Aboriginal companions. 'They walked stoutly', wrote Tench, 'appeared but little fatigued, and maintained their spirits admirably'. They also laughed 'to excess when any of us tripped or stumbled; misfortunes which much seldomer fell to their lot than to ours'; another reminder that the authoritative colonial gaze was also returned, the capabilities of the colonists were being examined and weighed. ${ }^{45}$ Voluntarily sharing knowledge, Colebee and Balloderry told the party that this land was the country of the Bidjigals and, referring to the smallpox epidemic, said that most had died. ${ }^{46}$ Later, they passed into another territory, that of the Buruberongal, a people that Colebee described as 'bad', and that as they had no fish, they lived on birds and animals. ${ }^{47}$

Here too were the first hints that 'travelling knowledge' was not foreign to Colebee and Balloderry. ${ }^{48}$ There was knowledge gained on travel for ceremonies, 'feasts of seasonal food' and trade across different territories, and there were strict protocols - not all Aboriginal people travelled into adjoining areas, though some linked by marriage and other alliances could move about widely. ${ }^{49}$ Colebee and Balloderry had either travelled here before, and so could read the landscape and knew where their country ended, or they had heard the relevant stories. ${ }^{50}$

\footnotetext{
42 Tench, 'Settlement at Port Jackson', 188.

43 Tench, 'Settlement at Port Jackson', 225.

44 Tench, 'Settlement at Port Jackson', 223-24; Hunter, Transactions at Port Jackson, 513.

45 Tench, 'Settlement at Port Jackson', 225; In many cases, the colonists were aware of this. Sydney Gazette, 17 April 1813, 2; Konishi, The Aboriginal Male, 3.

46 Hunter, Transactions at Port Jackson, 513.

47 Tench, 'Settlement at Port Jackson', 225.

48 Shellam, 'Manyat's “Sole Delight”, 121-32; Attenbrow, Sydney's Aboriginal Past, 79.

49 Attenbrow, Sydney's Aboriginal Past, 79.

50 See R. H. Mathews in Thomas, Culture in Translation, 150; Shellam, 'Manyat's "Sole Delight"'; Shellam, 'Nyungar Domains', 87.
} 
Nonetheless, signs of confounded expectations began to emerge even on the first day. The colonists had expected that Colebee and Balloderry would know the country intimately and be able to provide information - a telling expectation of utility to the colonists, a longstanding undercurrent in so many dealings in this colonial context as elsewhere. They also hoped to see how they drew subsistence from the land. ${ }^{51}$ Instead, as shall be discussed in more detail, they found that the further they went from Rose Hill, the less their Aboriginal companions knew of the country and the more dependent on the colonists they became.

\section{The two masters of ceremonies}

At camp after sunset, Colebee and Balloderry bade the expeditionary party be silent and listen carefully: voices could be heard in the dark. Here, the journals of Hunter and Tench disagree. Hunter remarked that it was Colebee and Balloderry who wanted to open conversation with these Aboriginal men, Tench that it the officers who 'begged' their guides 'to call to them, and bid them to come to us, to assure them of good treatment'. The latter seems more likely if the inhabitants of the area really were 'bad men and their enemies'. ${ }^{52}$ Either way, with knowledge of the colonists' directions, intentions and their arms if needed, Colebee whooped aloud, and the signal was returned. This continued back and forth until the voices drew closer. As a lit timber torch was seen shining in the dark, Colebee and Balloderry moved forward, only to retreat again and ask the sergeant to go with them with his gun - a request that was declined, but that points to other relationships and cooperation in the expeditionary unit that frequently go unrecorded.

The man and boy who approached were also careful, and, while again both accounts have slightly different detail, communication began, with each person stating his name and affinity. Balloderry then explained to them who the colonists were, calling them 'white men and friends, who would give him something to eat'. Though he appeared uncertain about how to proceed, Bereewan (Burrowan, for Hunter), drew the man to their fire and introduced each of the 21-person expeditionary party by name. The party were further described as 'Englishmen, and Bùd-yee-ree (good), that we came from the sea coast, and that we were travelling inland'. Here, cultural brokerage had happened organically, a circumstance not lost on Tench, who called Colebee and Balloderry our 'two masters of the ceremonies'. This lengthy conversation continued between Colebee and Balloderry, while the colonists remained mute on the sidelines. Bereewan then left when the gifting of provisions by the colonists signalled the end of the meeting..$^{33}$

51 For instance, Ballantyne, 'Strategic Intimacies'.

52 Hunter, Transactions at Port Jackson, 514.

53 Tench, 'Settlement at Port Jackson', 226. 


\section{Travelling continues}

The second day was equally fatiguing for the colonists and their difficulties navigating the terrain continued, much to the amusement of Colebee and Balloderry who 'wound' through timber, vines and nettles with ease, and in the colonists' troubles continued to find 'an inexhaustible fund of merriment and derision'. ${ }^{54}$ As the party went along, ducks were shot at, but only one was struck, and Colebee swam for it. They also passed signs of the local inhabitants, including one man who fled, and a hut. Again, the accounts disagree: either they did cut the hut to pieces, or Phillip prevented them. Either way, Colebee and Balloderry seemed displeased at interference in actions taken against their enemies.

Increasingly, Colebee and Balloderry were becoming strangers to the country being travelled through. Coming across a new river, they 'stared at it with surprise, and talked to each other', and in a telling sign that the colonists were testing them, they were asked which way Rose Hill lay and pointed completely in the wrong direction. Instead, they too came to rely on the compass, calling it 'Nää-Mòro', or 'To see the way'. ${ }^{55}$ Yet what is curious here is that Colebee and Balloderry were not completely ignorant, as the colonists suggested. They knew when they were passing through the country of the Bidjigals, and they knew when they passed onto the country of the Buruberongal too. So Colebee and Balloderry knew the landscape, the stories and the markers that signalled whose country one was in, even when such signs were invisible to the expeditionary party. ${ }^{56}$

The country was more difficult the following day, and the party spent most of it clambering over rocks and scrub with little grass. Once more, Colebee and Balloderry delighted in the colonists' misfortunes and gleefully mimicked their falling into nettles and slipping down the rocks. All at the camp that evening were exhausted, save 'our two sable companions', who, after they had received their food, 'began to play ten thousand tricks and gambols', imitating 'the leaping of the kangaroo' and singing, dancing, and play-fighting with spears. They were also asking more urgently for when the colonists would return. Pointing to where they were, they cried “"Weè-ree, Weè-ree” (bad)', before contrasting this with Rose Hill and Sydney, saying, 'Bud-ye-ree, Bud-ye-ree (good)'. 'At Rose Hill', Colebee and Balloderry said, were 'potatoes, cabbages, pumpkins, turnips, fish and wine: here are nothing but rocks and water'. Tench wrote that 'these comparisons constantly ended with the question of "Where's Rose Hill; where?" on which they would throw up their hands, and utter a sound to denote distance, which is impossible to convey an idea of upon paper'. 57

54 Hunter, Transactions at Port Jackson, 516; Tench, 'Settlement at Port Jackson', 226-27.

55 Tench, 'Settlement at Port Jackson', 227.

56 Shellam, 'Manyat's "Sole Delight"'.

57 Tench, 'Settlement at Port Jackson', 227-29. 


\section{'All sides continued to chat and entertain each other'}

The next day, following a long bed of stones that looked like 'a pavement formed by art', the expeditionary unit reached a river and spotted several canoes. Colebee and Balloderry directed the rules of engagement once more and had the party of 21 drop down amidst the reeds. Then, they took the lead in calling to the party, and one, a man of the name Gombeeree being known to Colebee, paddled over. Questions were asked about the river, which he responded to and, having been told by Colebee and Balloderry the importance of the Governor, Gombeeree returned and gave Phillip 2 stone hatchets and 2 spears - he too wanted to further this relationship with this important white man. Phillip, returning the diplomatic gesture, gave 2 axes, some fish hooks and some bread. Colebee had to broker meanings here, telling Gombeeree that the latter was food. ${ }^{58}$

When the expeditionary unit pushed on along the riverbank, Gombeeree followed the party in his canoe, another canoe joining behind him. Noting that the colonists were struggling in their travel, he observed that they were not walking close enough to the water's edge where the most comfortable path lay. Still the expeditionary party had difficulty, so Gombeeree got out of his canoe and, leading them, brought them to the path that his own people used along the river. When the colonists stopped to make camp that afternoon, they realised that their new companion would camp with them, as did a boy named Deeimba and a young man called Yellomundee.

The colonists were surprised by these Aboriginal people's confident and effortless interaction. 'The ease with which these people behaved among strangers, was as conspicuous, as unexpected', wrote Tench, continuing, 'they seated themselves at our fire, partook of our biscuit and pork, drank from our canteens' and, ever anxious to test the effect of their guns on new Aboriginal people, noted that they 'heard our guns going off around them, without betraying any symptom of fear, distrust or surprise'. ${ }^{59}$ This party may not have been in direct contact with the colonists, but they were well informed. The colonists, perhaps used to the remonstrations of Barangaroo, noted that the women who stayed on the opposite bank were content and showed no fear of their designs towards their men. ${ }^{60}$

As Martin Thomas has argued, all expeditions, by virtue of the fact that they were intrusions on inhabited terrain, were 'intercultural phenomena' and so became 'vehicles for cultural display and inquiry' in the process. ${ }^{61}$ The exchanges across the camp that

58 Tench, 'Settlement at Port Jackson', 229; Hunter, Transactions at Port Jackson, 519.

59 Tench, 'Settlement at Port Jackson', 230. On colonists and the use of sound, see Buchan, 'The Civil Noise of Empire'.

60 Tench, 'Settlement at Port Jackson', 230.

61 Thomas, 'What Is an Expedition?', 4. 
evening were precisely in this tone, with all the 'mutual curiosity and preparedness to engage' that, as Philip Jones has noted, was characteristic of early encounters. ${ }^{62}$ Some of the expeditionary party, their curiosity piqued by Colebee and Balloderry who called these people the Buruberongal men, 'climbers of trees', pressed Gombeeree to climb one $-\mathrm{a}$ feat at which he was considered a master despite being an older man - and gave him biscuit upon completion. ${ }^{63}$ The colonists' probing continued, and they discovered that as there was only mullet in the rivers, the local Aboriginal people hunted mainly small marsupials and collected roots. The questions asked of the Buruberongal were communicated through Colebee and Balloderry, who the colonists discovered understood this group perfectly, and vice versa, despite speaking different dialects. ${ }^{64}$ Here, in a proto-ethnographic style, the words for the moon, the ear, forehead, belly, navel, buttocks, neck, thigh and hair, among others, were all written down and compared with the terms heard at Sydney Cove. ${ }^{65}$ Balloderry and Colebee also became true 'masters of ceremonies' that night, refusing to ask the Buruberongal questions about their initiation ceremonies, as private, sacred matters requiring circumspection. 'Neither Colebee, nor Boladeree [Balloderry], would put the question for us', Tench wrote, 'and on the contrary, shewed every desire to waive the subject'. ${ }^{66}$

Tench and other officers had long been curious about the politics of the different Indigenous groups around the colony. In considering why Colebee and Balloderry would not put their question to the Buruberongal, Tench reflected that this was further proof that the extraction of the front tooth among the Cammeraigal about Sydney was an imposition by this strong people - some of their closest acquaintances - upon weaker groups around them. They also deduced that since Colebee and Balloderry had labelled these people as 'bad', that their people of the sea coast must have driven these people inland to maintain their stock of fish, 'the weaker here, as in every other country, giving way to the stronger' ${ }^{67}$ Confusingly for the colonists, when the Buruberongal were out of earshot, their Aboriginal companions 'spoke of them very lightly' despite being 'on very friendly terms with their new acquaintances', and Yellomundee, the youngest of the men, was described as particularly bad by Balloderry ${ }^{68}$ Here, it is difficult to know whether or not Balloderry was reflecting the political realities as he perceived them, or was deliberately striving to turn the colonists off developing close relationships with Buruberongal. ${ }^{69}$

\footnotetext{
62 Jones, 'The Theatre of Contact'.

63 Hunter, Transactions at Port Jackson, 520-21; Tench, 'Settlement at Port Jackson', 233.

64 On the difficulty of knowing exact clan boundaries in this area of Sydney, including a discussion of the Bediagal and the Buruberongal, see Attenbrow, Sydney's Aboriginal Past, 24-34.

65 Tench, 'Settlement at Port Jackson', 231; Hunter, Transactions at Port Jackson, 523; Shellam, 'Ethnographic Inquiry', 237.

66 Tench, 'Settlement at Port Jackson', 230.

67 Tench, 'Settlement at Port Jackson', 225.

68 Tench, 'Settlement at Port Jackson', 225.

69 Kathleen du Val has argued that in the Arkansas Valley, 'Indians and Europeans alike sought to control the culture of diplomacy and trade and to define themselves and others in ways that forwarded their own interests'. Kathleen du Val, The Native Ground, 4.
} 
The camp that night was friendly and convivial. All sides were 'stretched out at ease' and 'continued to chat and entertain each other' ${ }^{70}$ Yet the conversations and interactions had moved from being dyadic to triadic. ${ }^{71}$ They were increasingly dominated by the Cammeraigal and the Buruberongal, and it seemed that little was translated back to the colonists who were straining to catch and understand what words they could. Gombeeree showed them a scar on his side, the result of a significant spear wound, and then explained the circumstances surrounding it. From the officers' journals, it is clear that the stories of conflict and battle surrounding such scarring was a frequent subject of communication between Aboriginal men, a site of knowledge exchange, performance and construction of self to the other, as well as a way of narrating the political landscape and one's place in it. ${ }^{72}$ In return, Colebee then related knowledge of his own: who the colonists were, their numbers at Sydney and Rose Hill, of their stores of goods, and 'above all', wrote Tench, 'the good things which were to be found among us, enumerating potatoes, cabbages, turnips, pumpkins'. Hunter added that the names of people were also 'particularly attended to as if their hearers had been intimately acquainted with every person who was mentioned'. ${ }^{73}$ Tench also noted that despite the fact that these words were mainly in English, and were 'perfectly unintelligible to the person who heard them', nonetheless, Gombeeree listened with 'profound attention': they, like the colonists, were collecting intelligence. ${ }^{74}$

Exchanges continued between Colebee, Balloderry and the Buruberongal, this time of specialised services: Yellomundee was a "caradyee", or "Doctor of renown", as was his clan. Colebee asked for water and, upon being given a cup by one of the expeditionary party, presented it with 'great seriousness' to Yellomundee, who then spat water upon him, and began to suck at his chest. This was a process repeated once or twice and, with the arts of this medicine man, 2 splinters from spears were thereby removed. ${ }^{75}$ While Tench considered it a feat of trickery, Colebee was delighted and fully assured that he 'had received signal benefit from the operation', giving most of his supper to Yellomundee in return for his healing services, as well as his nightcap. ${ }^{76}$ The next morning, a nod of the head between the Aboriginal parties and a 'lustily' returned handshake from the colonists ended the amicable meeting, the differentiated protocols of departure signalling a growing understanding of separate codes of politeness between the Aboriginal and colonial cultures. ${ }^{77}$

\footnotetext{
70 Tench, 'Settlement at Port Jackson', 231.

Metcalf, Go-betweens, 2.

McLaren, 'Entangled Life of Goggey', 499.

Tench, 'Settlement at Port Jackson', 232; Hunter, Transactions at Port Jackson, 522.

Tench, 'Settlement at Port Jackson', 232.

The accounts differ on the number of times this ceremony was performed. The classic yet controversial study

of Aboriginal medicine men is Elkin, Aboriginal Men.

76 Tench, 'Settlement at Port Jackson', 232; Hunter, Transactions at Port Jackson, 522.

77 Tench, 'Settlement at Port Jackson', 233.
} 


\section{'No house now, no fish, no melons'}

Colebee and Balloderry had long been perplexed by this expedition, but on the fifth day tensions reached their height. Hunter had already tried 'to convey to their understandings the intention of our journey', but found it impossible: 'perhaps, no words could unfold to an Indian, the motives of curiosity, which induce men to encounter labour, fatigue, and pain, when they might remain in repose at home, with a sufficiency of food', he continued, revealing how, to him, the deficit of purpose was linked with the indolence of the savage state. ${ }^{78}$ Hunter wrote that Colebee and Balloderry 'had at first supposed, that Governor Phillip and his party came from the settlement to kill ducks and patagorongs [kangaroos]', only to be confused when the expeditionary party was not stopping at the places where large numbers of these animals had been seen. So upon questions being put to the Buruberongal about the rivers, Colebee and Balloderry then thought that the journey was to 'procure stone hatchets', and so communicated to the colonists that 'it was a great way to the place where the stone hatchets were to be procured and that they must come in a boat', asking the Governor to return to Rose Hill. ${ }^{79}$ Then, as already related, repeated questions were asked about the direction of Rose Hill, along with opinions that it was a much better place than the country where they were at present.

On this morning, Balloderry had also refused to swim for some ducks that been shot. When asked why, he told the party that the white man ate whatever they swam for, despite them having to take the trouble to fetch it. It was a revealing observation. Accompanying the Governor on this expedition were 2 of the Aboriginal men who dined with him most often, sitting at table with knife and fork, and who drank wine with relish. ${ }^{80}$ Yet on this expedition, the hierarchies subverted at Phillip's dinner table in his eagerness to conciliate key Aboriginal individuals about Sydney - Julie McIntyre has aptly called it 'dinner-table diplomacy' - and again on display with the colonists giving the usually unencumbered Colebee and Balloderry only a light pack, had hardened into an order that did not sit well with their Aboriginal companions. ${ }^{81}$ Balloderry's reproof was 'too justly founded', noted Tench. Of the few ducks shot, 'little had fallen to their share, except the offals, and now and then a half-picked bone'. While crows and hawks that were shot were given to them, 'they plainly told us that the taste of ducks was more agreeable to their palates; and begged they might hereafter partake of them' ${ }^{82}$ In admitting this reality, the colonists had unwittingly fallen back on the hierarchical and class customs of their own culture, forgetting that protocols around the distribution of food also permeated the world of their companions, and that to refuse to offer food, or to refuse to accept it, could be

78 Tench, 'Settlement at Port Jackson', 225.

79 Hunter, Transactions at Port Jackson, 519.

80 Hunter, Transactions at Port Jackson, 513; Smith, 'Woolarawarre Bennelong'.

81 McIntyre, “"Bannelong Sat Down”, 39.6.

82 Tench, 'Settlement at Port Jackson', 234. 
understood as a calculated snub. ${ }^{83}$ But perhaps more significantly, this happening pointed to structural violence, writ small. Balloderry's refusal to meet the colonist's request signalled his refusal of the exchange system in operation, one in which the social and material flows had ceased to be mutually agreeable. ${ }^{84}$

It was also promising to be an uncomfortable night: sprinkles of rain were threatening to turn heavy, and they had no tent for the evening. 'Where's Rose Hill; where?', Colebee and Balloderry both asked incessantly. Colebee then talked about his wife and child, saying that the latter would cry, thereby introducing a gendered element of social obligation into the equation. Balloderry also 'lost all patience when the rain began, telling the Governor that there were good houses at Sydney and Rose Hill, but that they had no house now, no fish, no melon' (to the last, Hunter added in parentheses, 'of which fruit all the natives are very fond'). ${ }^{85}$ Hunter also observed that their Aboriginal companions would have abandoned the party, had they known the way home. ${ }^{86}$

The next morning, when the expedition was called off, Colebee and Balloderry were delighted. When the party reached Rose Hill, the punt was leaving for Sydney Cove. They went straight aboard, eager - according to Tench - to 'communicate to Baneelon [Bennelong], and the rest of their countrymen, the novelties they had seen'. ${ }^{87}$ While Tiffany Shellam has convincingly argued for the prestige associated with 'travelling knowledge' at King George Sound, ideas that could and possibly do apply to this episode, returning to kin was probably a significant factor here as well. ${ }^{88}$

\section{Webs of stories}

Following this failed expedition in April, another took place in May, with 3 or possibly 4 of the participants in the previous journey among the company. This time, however, no Aboriginal 'guides' asked to go along. In this earlier period, before the skills of Aboriginal guides as cooks, hunters, trackers and interpreters had developed, not all colonists were convinced of the utility of Aboriginal guides in the most straightforward sense of the term: as individuals who were familiar with the land and so would be able to direct and lead. ${ }^{89}$ This expedition of May 1791 was to try to ascertain, once more, whether the Hawkesbury and the Nepean were, in fact, one river. While Tench was nailing his exploratory credentials to the wall - he wrote that this excursion 'completely

\footnotetext{
83 McLaren, 'Entangled Life of Goggey'.

84 On ways of grappling with different 'schemes of reciprocities', see Sahlins, Stone Age Economics, 194-96.

85 Hunter, Transactions at Port Jackson, 524.

86 Hunter, Transactions at Port Jackson, 524.

87 Tench, 'Settlement at Port Jackson', 234.

88 Shellam, 'Manyat's “Sole Delight”, 121-32.

89 Gregory Blaxland, the leader of the expedition that crossed the Blue Mountains in 1813, deliberately chose not to harness an Aboriginal guide to come along as earlier he had found they contributed little. Blaxland, A Journal of a Tour of Discovery Across the Blue Mountains, 12.
} 
settled the long-contested point' about these rivers and that he and Dawes had in fact unknowingly been this way a full year earlier - they again encountered a local Aboriginal man. This man, Deedora, called out to them using a 'native call'. So they answered, and when he came closer, they 'conversed across the river', though in one of the shortfalls of these journals it is not explained how they communicated, whether by gesture or spoken language. ${ }^{90}$

What is curious about this and subsequent happenings is that Deedora initiated them. It was Deedora who cooeed from the bush and then paddled across the river 'without distrust or hesitation'. ${ }^{91}$ It was also Deedora who presented the colonists with 2 spears and a throwing stick: gifts that were exchanged for bread and beef. Then, finding that their party was heading up the river, Deedora offered to accompany them and paddled along until they reached Richmond Hill, where they had to cross the river. Here, the colonists' new escort offered his craft and called to friends on the opposite shore so that they were prepared for the strangers. Dawes and the soldier stripped and put their clothes in the canoe, pushing it ahead of them as they swam across. Morùnga, one of the Aboriginal people on the other side of the river, brought the craft back across. Tench and his companion struggled with the canoe, both being frightened of rivers and swimming to various degrees. Knight, in particular, was subject to ridicule, with Morùnga 'making signs of the ease and dispatch with which he would land him'. Yet both he and Tench were fearful of the water, a fact that was not lost on Deedora. Serjeant Knight eventually steered his way across while Tench decided to swim. Tench's clothes, half their knapsacks and 3 guns were then transported over by their new acquaintances who 'delivered them ... without damage or diminution' ${ }^{92}$

In the face of such unbridled confidence, it is telling that Deedora 'appeared to know Gombeeree, of whom he often spoke'. ${ }^{33}$ It is also significant that, during what Tench recognised as his party's 'helplessness and dependence', there was 'no rude curiosity to pry into the packages with which they were intrusted; or no sordid desire to possess the contents of them; although among them were articles exposed to view, of which it afterwards appeared they knew the use of, and longed for the benefit'. ${ }^{4}$ When a hawk was later shot and fell into a tree, Deedora, knowing the colonists were not able to climb, offered his services. ${ }^{95}$ Having been passed a metal hatchet to climb the tree and liking its utility, he requested it, and it was given to him the next morning. ${ }^{96}$

\footnotetext{
90 For a discussion on the difficulties of body language communication, see Greenblatt, Marvellous Possessions, 86-118; Clendinnen 2002, 157-74; Shellam, 'Mediating Encounters', 85-102, especially 97.

91 Tench, 'Settlement at Port Jackson', 235.

92 Tench, 'Settlement at Port Jackson', 236.

93 Tench, 'Settlement at Port Jackson', 235.

94 Tench, 'Settlement at Port Jackson', 236.

95 The botanist George Caley valued this skill highly, and would not travel without a guide. Smith, Mari Nawi, 124.

96 Tench, 'Settlement at Port Jackson', 236-37.
} 


\section{Conclusion: Dynamic exchanges}

What can be drawn from these accounts? The first point to be made is that Colebee and Balloderry had entirely misconstrued the purpose of the expeditionary party, did not know what it meant to guide and had different expectations from those of the colonists. On the first night Colebee and Balloderry did not help set up camp, or chop wood for the fire, but ate and were waited upon. While later in the colony Aboriginal people knew what the colonists wanted in a guide, offered their skills and negotiated their payment, in 1791 these understandings had yet to develop.

It is also clear that the phenomenon of guiding was dependent upon the satisfactory negotiation of the needs of each party, needs that could be very different, and sometimes opposed. Pointing to this reality was the fact that Colebee and Balloderry would not put the questions to the Buruberongal that the colonists had asked them to; their asking of the sergeant to protect them with his gun; their unshakeable desire to return to Rose Hill; and their refusal to help with any more bird hunting. So the dynamics within expeditionary units themselves could be unstable, with different desires and interests at play. The decision to travel with an expeditionary party in the first place also required negotiation. Philip Jones has noted that those individuals who acted as guides 'were often torn between the great personal benefit and material reward associated with being part of an expedition ... and their ambivalences at leaving behind the security of their own countries, languages and kin' ${ }^{97}$ While this was only a relatively short expedition of 6 days rather than the weeks or months of other, much larger expeditions, it too had required Colebee to consider how he could both travel with the colonists and acquit his duties to his family. He negotiated with the colonists for this to happen. He would go, but only if his wife and child would be sheltered and fed by the colonists in Sydney.

In her consideration of the beginnings of guiding at King George Sound, Shellam noted a similar dynamic. Mokaré, a King-ya-nup man, had been misled by surgeon and explorer Thomas Braidwood Wilson in 1829, who deliberately failed to communicate just how far they were travelling. ${ }^{98}$ The result was that 5 days into the expedition, Mokaré 'entered into a serious remonstrance' with Wilson, saying that they had little food, were far from King George Sound and that this was a far longer distance than the others usually travelled. Mokaré also added - not dissimilarly to Colebee - that 'the white fellows would cry'. ${ }^{99}$ Travel was all well and good, but both Mokare and Colebee were also thinking about all the people, Indigenous and non-Indigenous, left behind, and the travelling parties' other social obligations.

97 Jones, 'The Theatre of Contact', 97.

98 Shellam, Shaking Hands, 144.

99 Shellam, Shaking Hands, 145. 
What of Deedora in the second short expedition related here? A perspective attentive to regional politics offers one explanation. It is probable that Deedora knew about these colonial people and his kinsfolk's experiences with them - including their goods and the presence of 2 foreign Aboriginal men - from the larger expedition of the preceding month. Perhaps the incident related above was an example of cultural curiosity of some form, mixed with a sense of acquisitiveness or a desire to engage with these powerful 'bud-ye-ree' (good) Englishmen, as Colebee and Balloderry described the colonists to the Buruberongal a month earlier.

Even if Deedora's action was an 'example of disinterested urbanity', as Tench called it, it was not an ignorant one. ${ }^{100}$ In repeatedly mentioning Gombeeree, Deedora was establishing his relationships with him, and in the process inadvertently left a clue to the ways in which knowledge about the colonists was gathered and how it spread. After all, Gombeeree had listened in 'rapt attention' to the news about the colonists' settlement at Sydney and Rose Hill, and the foods to be found there, and who had been given a metal axe and a nightcap. ${ }^{101}$ He had also seen the colonists' ineptitude at travelling alongside the river, their tumbles and struggles, and had shown them the way. Alternatively, Deedora's actions could be read as an example of what Baker called the guiding of the 'passers on': those Aboriginal people who assisted intruding expeditionary parties 'through their territory with as little fuss and damage as possible'. ${ }^{102}$ Either way, Deedora had learnt who these colonists were, what they carried, and their limited skills when travelling country - another reminder of the currents of stories and news that flowed around the colonists, stories that affected their reception.

It is worth dwelling further upon the fact that Gombeeree, seeing the colonists' struggle along the riverbank, responded by taking it upon himself to lead them through the country he knew so well. Another consequence of the colonists' travel was that it brought about circumstances in which both the limitations of their knowledge and of their skill could clearly be seen. The colonists had not asked for guiding help, but it had been offered by Gombeeree nonetheless. Similarly, the colonists had not, at this stage, brought along Aboriginal men to act as cultural brokers, yet circumstances on the ground brought this practice about. Here too, we can see that these exchanges developed dynamically through the circumstances and relationships the colonial presence in New South Wales set in motion.

100 Tench, 'Settlement at Port Jackson', 236.

101 Tench, 'Settlement at Port Jackson', 232; Hunter, Transactions at Port Jackson, 522.

102 Baker, 'Exploring with Aborigines', 40. 


\section{References}

\section{Primary sources}

Atkinson, James. An Account of the State of Agriculture \& Grazing in New South Wales. London: J. Cross, 1826.

Blaxland, Gregory. A Journal of a Tour of Discovery across the Blue Mountains, New South Wales, in the Year 1813. Sydney: Australian Historical Society, 1913.

Hunter, John. An Historical Journal of the Transactions at Port Jackson and Norfolk Island with the Discovers Which Have Been Made in New South Wales and in the Southern Ocean, since the Publication of Phillip's Voyage, Compiled from the Offical Papers; Including the Journals of Governors Phillip and King, and of Lieut. Ball; and the Voyages From the First Sailing of the Sirius in 1787, to the Return of That Ship's Company to England in 1792. Adelaide: Libraries Board of South Australia, 1968 [1793].

Sydney Gazette and New South Wales Advertiser (Sydney Gazette).

Tench, Watkin. 'A Complete Account of the Settlement at Port Jackson', published as Sydney's First Four Years, edited by L. F. Fitzhardinge. Sydney: Library of Australian History, 1979 [1793].

\section{Secondary sources}

Attenbrow, Val. Sydney's Aboriginal Past: Investigating the Archaeological and Historical Records. Sydney: UNSW Press, 2010 [2002].

Baker, Don. 'Exploring with Aborigines: Thomas Mitchell and His Aboriginal Guides'. Aboriginal History 22 (1998): 36-50. doi.org/10.22459/AH.22.2011.03.

Ballantyne, Tony. 'Strategic Intimacies: Knowledge and Colonization in Southern New Zealand'. Journal of New Zealand Studies, no. 14 (2013): 4-18. doi.org/10.26686/jnzs. v0i14.1744.

Blyton, Greg. 'Harry Brown (c. 1819-1854): Contribution of an Aboriginal Guide in Australian Exploration'. Aboriginal History 39 (2015): 63-82. doi.org/10.22459/AH.39. 2015.03.

Buchan, Bruce. 'The Civil Noise of Empire'. In Sound, Space and Civility in the British World, 1700-1850, edited by Peter Denney, Bruce Buchan, David Ellison and Karen Crawley. Crawley, WA: Ashgate, 2018. doi.org/10.4324/9781315609942.

Buchan, Bruce. Empire of Political Thought: Indigenous Australians and the Language of Colonial Government. London: Pickering \& Chatto Publishers, 2009.

Clendinnen, Inga. Dancing With Strangers: Europeans and Australians at First Contact. Cambridge: Cambridge University Press, 2005. 
Clendinnen, Inga. 'Spearing the Governor'. In 'Challenging Histories: Reflections on Australian History', special issue. Australian Historical Studies 33, no. 118 (2002): 157-74. doi.org/10.1080/10314610208596189.

Conor, Liz. Skin Deep: Settler Impressions of Aboriginal Women. Crawley, WA: University of Western Australia Press, 2016.

Dening, Greg. 'The Theatricality of Observing and Being Observed: Eighteenth-Century Europe "Discovers" the "Pacific". In Implicit Understandings: Observing, Reporting and Reflecting on the Encounters between Europeans and Other Peoples in the Early Modern Era, edited by Stuart B. Schwartz, 451-83. Cambridge: Cambridge University Press, 1994.

Douglas, Bronwen. 'In the Event: Indigenous Countersigns and the Ethnohistory of Voyaging'. In Oceanic Encounters: Exchange, Desire, Violence, edited by Margaret Jolly, Serge Tcherkézoff and Darrell Tryon, 175-98. Canberra: ANU E Press, 2009. doi.org/ 10.22459/OE.07.2009.06.

Douglas, Bronwen. 'Philosophers, Naturalists, and Antipodean Encounters, 1748-1803'. Intellectual History Review 23, no. 3 (2013): 387-409. doi.org/10.1080/17496977.2012. 723343 .

Douglas, Bronwen. Science, Voyages, and Encounters in Oceania, 1511-1850. Basingstoke: Palgrave Macmillan, 2014. doi.org/10.1057/9781137305893.

Downing, Karen. Restless Men: Masculinity and Robinson Crusoe, 1788-1840. Hampshire: Palgrave Macmillan, 2014.

Driver, Felix. Geography Militant: Cultures of Exploration and Empire. Oxford: Wiley, 2000.

Dunn, Mark. 'Aboriginal Guides in the Hunter Valley, New South Wales'. In Brokers and Boundaries: Colonial Exploration in Indigenous Territory, edited by Tiffany Shellam, Maria Nugent, Shino Konishi and Allison Cadzow, 61-84. Canberra: ANU Press, 2016. doi.org/10.22459/BB.04.2016.04.

Edwards, Gavin. 'Watkin Tench and the Cold Track of Narrative'. Southerly 60, no. 3 (2000): 74-93.

Elkin, A. P. Aboriginal Men of High Degree. Sydney: Australasian Publishing, 1945.

Fabricant, Carol. 'Eighteenth-Century Travel Literature'. In The Cambridge History of English Literature, 1660-1780, edited by John Richetti, 704-44. Cambridge: Cambridge University Press, 2005. doi.org/10.1017/CHOL9780521781442.029.

Favenc, Ernest. The History of Australian Exploration from 1788 to 1888. Sydney: Turner and Henderson, 1888.

Fullagar, Kate. Savage Visit: New World People and Popular Imperial Culture in Britain. 1710 1795. Berkeley: University of California Press, 2012.

Goodall, Heather and Allison Cadzow. Rivers and Resilience: Aboriginal People on Sydney's Georges River. Sydney: UNSW Press, 2009. 
Govor, Elanor. Twelve Days at Nuku Hiva: Russian Encounters and Mutiny in the South Pacific. Honolulu: University of Hawai'i Press, 2010.

Greenblatt, Stephen. Marvellous Possessions: The Wonder of the New World. Oxford: Oxford University Press, 1991. doi.org/10.7208/chicago/9780226306575.001.0001.

Groom, Linda. A Steady Hand: Governor Hunter \& His First Fleet Sketchbook. Canberra: National Library of Australia, 2012.

Jones, Philip. 'The Theatre of Contact: Aborigines and Exploring Expeditions'. In Expedition into Empire: Exploratory Journeys and the Making of the Modern World, edited by Martin Thomas, 88-107. New York: Routledge, 2015. doi.org/10.4324/9781315756424-5.

Karskens, Grace. The Colony: A History of Early Sydney. St Leonards, NSW: Allen \& Unwin, 2009.

Konishi, Shino. The Aboriginal Male in the Enlightenment World. London: Pickering \& Chatto Publishers, 2012.

Konishi, Shino. 'Bennelong and Gogy: Strategic Brokers in Colonial New South Wales'. In Brokers and Boundaries: Colonial Exploration in Indigenous Territory, edited by Tiffany Shellam, Maria Nugent, Shino Konishi and Allison Cadzow, 15-38. Canberra: ANU Press, 2016. doi.org/10.22459/BB.04.2016.02.

Konishi, Shino. "'Wanton with Plenty" Questioning Ethno-Historical Constructions of Sexual Savagery in Aboriginal Societies, 1788-1803'. Australian Historical Studies 39, no. 3 (2008): 356-72. doi.org/10.1080/10314610802263331.

Konishi, Shino, Maria Nugent and Tiffany Shellam, eds. Indigenous Intermediaries: New Perspectives on Exploration Archives. Canberra: ANU Press, 2015. doi.org/10.22459/ II.09.2015.

Liebersohn, Harry. The Travelers' World: Europe to the Pacific. Cambridge, MA: Harvard University Press, 2006. doi.org/10.4159/9780674040236.

McIntyre, Julie. "'Bannelong Sat Down to Dinner with Governor Phillip, and Drank His Wine and Coffee as Usual": Aborigines and Wine in Early New South Wales'. History Australia 5, no. 2 (2008): 39.1-39.14. doi.org/10.2104/ha080039.

McLaren, Annemarie. 'Reading the Entangled Life of Goggey, an Aboriginal Man on the Fringes of Early Colonial Sydney'. Ethnohistory 65, no. 2 (2018): 439-515. doi.org/ $10.1215 / 00141801-4451446$.

Merle, Isabelle. 'Watkin Tench's Fieldwork: The Journal of an "Ethnographer" in Port Jackson, 1788-1791'. In Oceanic Encounters: Exchange, Desire, Violence, edited by Margaret Jolly, Serge Tcherkézoff and Darrell Tryon, 191-220. Canberra: ANU E Press, 2009. doi.org/ 10.22459/OE.07.2009.07.

Metcalf, Alida C. Go-betweens and the Colonization of Brazil, 1500-1600. Austin: University of Texas Press, 2005. 
Nugent, Maria. Captain Cook Was Here. Cambridge; Port Melbourne, Vic.: Cambridge University Press, 2009.

Sahlins, Marshall. Stone Age Economics. Chicago: Aldine-Atherton, 1972.

Shellam, Tiffany. 'Ethnographic Inquiry on Phillip Parker King's Hydrographic Survey'. In Expeditionary Anthropology: Teamwork, Travel and the 'Science of Man', edited by Martin Thomas and Amanda Harris, 205-304. New York: Berghahn Books, 2018. doi.org/ 10.2307/j.ctvw04g1m.11.

Shellam, Tiffany. 'Manyat's "Sole Delight": Travelling Knowledge in Western Australia's Southwest, 1830s'. In Transnational Lives: Biographies of Global Modernity, 1700-Present, edited by Desley Deacon, Penny Russell and Angela Woollacott, 121-32. Basingstoke: Palgrave Macmillan, 2012. doi.org/10.1057/9780230277472_10.

Shellam, Tiffany. 'Nyungar Domains: Reading Gyalliput's Geography and Mobility in the Colonial Archive'. In Conflict, Adaptation, Transformation: Richard Broome and the Practice of Aboriginal history, edited by Ben Silverstein, 80-95. Canberra: Aboriginal Studies Press, 2018.

Shellam, Tiffany. Shaking Hands on the Fringe: Negotiating the Aboriginal World at King George's Sound. Crawley, WA: University of Western Australia Press, 2009.

Shellam, Tiffany, Maria Nugent, Shino Konishi and Allison Cadzow, eds. Brokers and Boundaries: Colonial Exploration in Indigenous Territory. Canberra: ANU Press, 2016. doi.org/10.22459/BB.04.2016.

Smith, Keith Vincent. 'Bennelong among His People'. Aboriginal History 33 (2009): 7-30. doi.org/10.22459/AH.33.2010.01.

Smith, Keith Vincent. 'Colebee', Dictionary of Sydney, 2008. Accessed 4 March 2017. dictionaryofsydney.org/entry/Colebee.

Smith, Keith Vincent. Mari Nawi: Aboriginal Odysseys. Sydney: Rosenberg, 2010.

Smith, Keith Vincent. 'Woolarawarre Bennelong', Dictionary of Sydney, 2008. Accessed 4 March 2017. dictionaryofsydney.org/entry/Woolarawarre_Bennelong.

Stanfield, Rachel. 'Looking Across, Moving Beyond'. In Indigenous Mobilities: Across and Beyond the Antipodes, edited by Rachel Stanfield, 1-33. Canberra: ANU Press, 2018. doi.org/10.22459/IM.06.2018.

Thomas, Martin, ed. Culture in Translation: The Anthropological Legacy of R. H. Matthews. Canberra: ANU E Press and Aboriginal History Inc., 2007. doi.org/10.22459/CT.09.2007.

Thomas, Martin, ed. Expedition into Empire: Exploratory Journeys and the Making of the Modern World. New York: Routledge, 2015. doi.org/10.4324/9781315756424. 
Thomas, Martin. 'The Expedition as a Cultural Form: On the Structure of Exploratory Journeys as Revealed by the Australian Explorations of Ludwig Leichhardt'. In Expedition into Empire: Exploratory Journeys and the Making of the Modern World, edited by Martin Thomas, 65-87. New York: Routledge, 2015. doi.org/10.4324/9781315756424-4.

Thomas, Martin. 'What Is an Expedition? An Introduction'. In Expedition into Empire: Exploratory Journeys and the Making of the Modern World, edited by Martin Thomas, 1-24. New York: Routledge, 2015. doi.org/10.4324/9781315756424-1.

du Val, Kathleen. The Native Ground: Indians and Colonists in the Heart of the Continent. Philadelphia: University of Pennsylvnia Press, 2006. doi.org/10.9783/9780812201826.

Veracini, Lorenzo. 'Settler Colonial Expeditions'. In Expedition into Empire: Exploratory Journeys and the Making of the Modern World, edited by Martin Thomas, 51-64. New York: Routledge, 2015. doi.org/10.4324/9781315756424-3. 
This text is taken from Aboriginal History, Volume 43, 2019, edited by Ingereth Macfarlane, published 2020 by ANU Press, The Australian National University, Canberra, Australia.

doi.org/10.22459/AH.43.2019.02 